JPSCR: Journal of Pharmaceutical Science and Clinical Research, 2021, 01, 20-32

DOI: 10.20961/jpscr.v6i1.38960

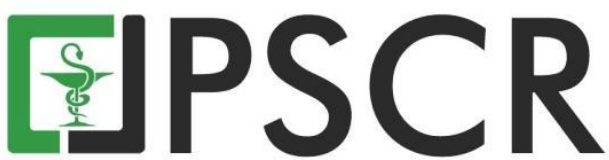

\title{
Analisis Pengendalian Persediaan Obat BPJS Kategori A(Always) Dan E (Esensial) Dengan Menggunakan Metode ABC, VEN Dan EOQ Di IFRS Bhayangkara Tingkat III Nganjuk
}

\author{
Nopandi Wisnu Darmawan*, Jason Merari Peranginangin dan Rina Herowati \\ Fakultas Farmasi Universitas Setia Budi, Jl. Letjen Sutoyo, Jebres, Surakarta, Jawa Tengah, Indonesia, 57127
}

*email korespondensi : nopandiwisnu@gmail.com

Received 12 January 2020, Accepted 22 September 2020, Published 15 March 2021

\begin{abstract}
Abstrak: Penelitian ini membahas tentang tata kelola obat-obatan di Rumah Sakit dengan manajemen seleksi, pengadaan, distribusi dan penggunaan obat secara rasional yaitu tepat obat, dosis dan biaya. Pemilihan obat kategori $A E$, karena obat kategori $A E$ memiliki tingkat kritis berdasarkan pada jumlah pemakaian tinggi dan dengan jumlah item obat yang banyak. Tujuan dilakukannya penelitian yaitu untuk melakukan analisa terhadap kendali obat BPJS kategori $A E$ menggunakan $\mathrm{ABC}$ and $\mathrm{VEN}$ method, menganalisa pengendalian ketersediaan obat obat BPJS dengan metode $E O Q$ dan $R O P$ dalam peningkatan obat menjadi efisien serta menganalisa tingkat pelayanan obat. Desain penelitian ini yaitu quasi experiment non-control. populasi semua obat BPJS yang ada di instalasi farmasi, sampel penelitaian adalah obat BPJS berdasarkan analisis metode $A B C$ dan $V E N$ kategori $A E$ pada bulan Februari sampai Juli 2019. Untuk mengamati sert amengukur tingkat keefesienan pada pengendalian ketersediaan obatobatan maka diberlakukan indikator nilai persediaan dan Customer servis level (tingkat pelayanan), penelitian yang sudah mendapatkan hasilnya, maka akan dilakukan pengujian statistik Paired $t$-Test. Dari uji analisis menggunakan metode $A B C$ dan VEN dapat mengidentifikasi obat yang memerlukan pengendalian persediaan yang lebih ketat dan memprioritaskan 29 item obat BPJS kategori $A E$. Indikator nilai persediaan dengan penerapan metode $E O Q$ dan $R O P$ sebelum intervensi Rp. 403.114 .341 dan setelah intervensi Rp. 331.170.915 dapat meningkatkan efesiensi pengelolaan obat BPJS dan menurunkan nilai persediaan sebesar Rp 71.943.426 berdasarkan hasil sebelum - sesudah intervensi menunjukkan hasil signifikan $(0,043)$. Indikator tingkat pelayanan (customer servis level) sebelum intervensi $91,76 \%$ dan setelah intervensi $94,39 \%$ berdasarkan hasil sebelum sesudah intervensi menunjukkan hasil signifikan $(0,025)$. Penggunaan metode $E O Q$ dan $R O P$ memudahhkan dalam perencanaan dan pengadaan serta merupakan upaya pengontrolan dan pemantauan persediaan obat agar obat yang diberikan tepat waktu dan kekosongan persediaan obat dapat dihindari.
\end{abstract}

Kata kunci: Obat BPJS Kategori AE; EOQ; ROP

Abstract: Analysis Of Drug Supply Control BPJS Category A (Always) And E (Essential), Using ABC, VEN And EOQ Methods In IFRS Bhayangkara Tk.III Nganjuk. Management of hospital drugs is an action that affect management functions including selection, procurement, distribution and rational use that is appropriate drugs, dosage and cost. The choice of category $A E$ drugs, because category $A E$ have a critical level with high nominal amount of usage and considerably drug items. The purpose of this study was to analyze BPJS drugs control category AE using $A B C$ and $V E N$ methods, analyze BPJS drugs inventory control with $E O Q$ and $R O P$ methods in improving drug efficiency and analyzing level of drugs services. Design of this study used a quasi-experimental without control, population were all BPJS drugs in pharmaceutical installations, sample taken from February to July 2019 were BPJS drugs based on analysis of $A B C$ and $V E N$ methods from category $A E$. Observation and measurement of drugs inventory control efficiency using 
indicators of inventory value and customer service level, results of this study was tested with Paired t-Test statistics. Results of this study were combination of $A B C$ and $V E N$ analysis methods could identify drugs that required strict inventory control and prioritize 29 items of BPJS $A E$ categories. Inventory value indicators with the application of the $E O Q$ and $R O P$ methods before intervention was Rp 403.114.341 and after intervention was Rp 331.170.915 might increase the efficiency of BPJS drugs management and reduce inventory value by $\mathrm{Rp}$ 71.943.426 based on results before - after intervention showed significant results $(0,043)$. Service level indicator (customer service level) before intervention was $91,76 \%$ and after intervention was $94,39 \%$ based on the results before - after the intervention showed significant result $(0,025) . E O Q$ and $R O P$ methods producing easy planning and procurement and to control and monitor medicine supply in order to given on time and the availability of medicine supplies could be maintained.

Keywords: BPJS Drugs Category AE; EOQ; ROP

\section{Pendahuluan}

Rumah sakit sudah seharusnya memberikan layanan yang memuaskan kepada masyarakat pada aspek kesehatan, tak terkecuali pada bidang farmasi. Sebagaimana dalam hal ini ditekankan pada Peraturan MenKes No 72 tahun 2016 (Permenkes, 2016) terkait dengan Pelayanan Farmasi Rumah Sakit, yang menyebutkan bahwa layanan bidangg farmasi pada sebuah rumah sakit tidak dapat terpisah dari orientasinya terhadap layanan yang diberikan kepada pasien, ketersediaan obat-obatan berkualitas, dan biaya yang relative dapat dijangkau masyarakat luas.

PerMen RI No. 28 tahun 2014 (Permenkes, 2014) menyatakan aturan tentang Pedoman Pelaksanaan Program Jaminan Kesehatan Nasional (JKN), sejak 1 Januari 2014 Badan Penyelenggara Jaminan Kesehatan (BPJS) mulai menyelenggarakan Jaminan Kesehatan Nasional (JKN) dan mengganti beberapa lembaga jaminan sosial. Sejak 15 Agustus 2018 BPJS melakukan sistem rujukan berjenjang dalam rangka kemudahan dan kepastian pelayanan peserta JKN. Dengan adanya sistem rujukan berjenjang mempengaruhi rencana dan strategi pengadaan di IFRS Bhayangkara Tk.III khususnya obat BPJS, karena jumlah pasien rawat jalan mengalami lonjakan hampir tiga kali dari sebelum adanya aturan rujukan berjenjang. Pembayaran klaim oleh BPJS terhadap health facilities tahap lanjutan melaui tarif Indonesia-Case Based Group (INA-CBG's). Tarif INA-CBG's berdasarkan paket layanan pengelompokan diagnosa penyakit, dalam pelaksanaan pembayaran klaim oleh BPJS sering meleset dari waktu yang semestinya sehingga mengakibatkan pengadaan obat di rumah sakit menjadi terganggu.

Obat-obatan berkategori $A E$, merupakan jenis pbat-obatan yang ditanggung BPJS yang membtuhkan atensi khusus terkait cara pengelolaannya. Obat kategori $A$ (always) menurut analisa $A B C$ mewakili obat dengan nominal harga yang tinggi, sedangkan obat kategori $E$ (esensial) menurut analisa VEN mewakili obat dengan jumlah yang banyak jenisnya. Obat 
BPJS kategori $A E$ masuk dalam jenis obat yang julah pemakaainnya dan itemnya banyak. Oleh sebab itu, Obat yang berada pada kategori $A E$ dibutuhkan atensi istimewa dan cara analisis yang benar. Untuk memberi saran terkait dengan pilihan metode yang benar tentang obat AE, pengelolaan obat di Instalasi Farmasi Rumah Sakit (IFRS) Bhayangkara Tk.III Nganjuk menjadi efektif dan efisien. Efisiensi pada tahap pengendalian persediaan dapat dilakukan dengan analisis $A B C$ (aspek ekonomi) dan metode Economic Order Quantity $(E O Q)$ yang diharapkan dapat menurunkan nilai persediaan, meningkatkan rasio perputaran persediaan (Inventory Turn Over Ratio), dan meningkatkan customer service level (tingkat pelayanan) (Quick et. al, 2012), belum pernah dilakukan di Rumah Sakit Bhayangkara Tk. III Nganjuk.

Penelitian ini bertujuan untuk melihat adanya pengaruh Nilai persediaan obat dan customer service level (tingkat pelayanan) di RS Bhayangkara Tk.III Nganjuk menjadi efektif dan efisien dengan cara memberlakukan metode EOQ dan Reorder Point (ROP).

\section{Metode}

Metode penelitian yakni quasi eksperimen tanpa kontrol. Artinya, untuk menyelesaikan suatu masalah penelitian secara terencana dan serius, tujuannya adalah untuk mendapatkan fakta dan kesimpulan untuk memahami, menjelaskan, memprediksi dan mengendalikan kondisi. Metode kuantitatif biasanya digunakan untuk menguji teori, menyatakan fakta atau mendeskripsikan statistik Syamsuddin dan Damayanti (2011). Dilakukan pada peningkatan efisiensi pengendalian persediaan obat dengan pengamatan secara berurutan waktu yaitu sebelum intervensi dan setelah intervensi. Rancangan penelitian ini diterapkan guna melihat seberapa tingkat keefisienan dalam menerapkan metode EOQ (Persamaan 1) dan ROP (Persamaan 2) pada persediaan obat dapat memperbaiki kinerja pengelolaan obat di IFRS Bhayangkara Tk.III Nganjuk. Populasi penelitian adalah seluruh obat BPJS kemudian sampel penelitian adalah obat BPJS dengan analisis $A B C$ dan $V E N$ yang termasuk kategori $A E$ selama periode bulan Februari sampai Juli 2019. Penelitian dilakukan di IFRS Bhayangkara Tk.III Nganjuk Melalui analisis kebutuhan obat berdasarkan analisis $A B C$ dan $V E N$. Efisiensi penyediaan obat dikendalikan dengan menerapkan metode $E O Q$ dan $R O P$ pada obat BPJS $A E$. Kedua indikator nilai persediaan dan tingkat pelayanan pelanggan digunakan untuk mengamati dan mengukur efisiensi pengendalian persediaan obat, kemudian hasil penelitian diuji dengan analisis paired t-test analysis.

Metode ABC. Metode ini merupakan penggolongan berdasarkan pada volum obat dan harganya sesuai dengan waktu yang ditentukan atau disebut juga dengan analisis pareto (Heizer and Render, 2011). Penggolongan metode ini yaitu 1) kategori $A$ yakni obat yang 
memerlukan pembiayaan sebesar $75 \%$ dan $20 \%$ total item obat, 2) kategori $B$ yakni jenis obat-obatan yang memerlukan $25 \%$ dari jumlah keseluruhan pem biayaan dan jumlah item obatnya $30 \%$ total item obat serta 3 ) kategori $C$ yakni obat-obata yang memerlukan biaya 5 $\%$ dari total ketersediaan obat yakni $50 \%$. Satibi (2015) menyatakan tahapan penentuan golongan $A, B$, dan $C$ adalah hitung jumlah dana yang dibutuhkan untuk setiap obat sesuai kuantum obat $\mathrm{x}$ harga obat, urutkan dari yang terbesar hingga terkecil, hitung persentase total dana yang dibutuhkan, dan hitung persentase kumulatif.

$$
E O Q=\sqrt{2 \mathrm{SD} / \mathrm{H}}
$$

Persamaan 1. Rumus perhitungan efisiensi pengendalian persediaan obat dengan metode EOQ. Jumlah pada per pesanan (EOQ), biaya pemesanan (ordering cost) setiap kali pesan (S), biaya penyimpanan (holding cost) per tahun $(\mathrm{H})$ dan kebutuhan (D).

Analisis $A B C$ diterapkan melalui beberapa prosedur yaitu 1) menentukan jumlah total pemakaian unit, 2) menghitung biaya total pemakaian dalam rupiah (total unit dikali dengan harga tiap-tiap obat), 3) menghitung presentase kumulatif yang terkait dengan jumlah masingmasing item obat dengan cara membagi jumlah item obat yang diberikan dengan jumlah total item obat, 4) menentukan total nilai kumulatif pemakaian rupiah pada tiap-tiap item obat yaitu melakukan pembagian jumlah item obat yang diberikan dengan jumlah total item obat, 5) Menentukan total nilai kumulatif pemakaian rupiah untuk masing-masing item obat, 6) menghitung presentase nilai obat kumulatif pemakaian untuk masing-masing item dengan cara jumlah total kumulatif dengan nilai kumulatif keseluruhan dan 7) menentukan klasifikasi yang tepat untuk masing-masing item obat. Obat klasifikasi $A$ merupakan presentase kumulatif hingga $70 \%$.

$$
\begin{gathered}
R O P=\mathrm{d} \times \mathrm{L} \\
\mathrm{d}=\mathrm{D} /(\text { Jumlah hari kerja }) \times \mathrm{L}
\end{gathered}
$$

Persamaan 2. Rumus perhitungan efisiensi pengendalian persediaan obat dengan metode $E O Q$. Kebutuhan per hari (d), kebutuhan bulanan (D) dan waktu tenggang (lead time) (L) (Handoko, 2003).

Metode VEN. Penentuan klasifikasi pasokan VEN berdasarkan faktor makro (seperti peraturan pemerintah atau data epidemiologi regional) dan faktor mikro (seperti jenis layanan medis yang dapat disediakan rumah sakit terkait). Jenis obat pada system $V E N$ yaitu 1) $V$ (vital) adalah obat yang terkandung dalam obat yang berpotensi menyelamatkan jiwa dan memiliki efek penarikan yang besar atau sangat penting dalam memberikan layanan kesehatan dasar, 2) $E$ (esensial) adalah obat yang efektif untuk menghilangkan rasa sakit, tetapi sangat penting untuk semua jenis obat, tetapi tidak penting untuk menyediakan sistem kesehatan dasar dan 3) $N$ (non-esensial) adalah obat yang digunakan untuk penyakit ringan 
atau penyakit tertentu, khasiat obat ini masih belum pasti, termasuk mahalnya biaya untuk mendapat manfaat pengobatan. Tahapan dalam penentuan obat berdasarkan jenisnya dengan metode VEN yakni dengan cara melakukan penyususnan, menyediakan data pola penyakit merujuk pada pedoman pengobatan.

Nilai persediaan. Nilai persediaan dalam rupiah, data-data yang dibutuhkan yaitu awal pemakaian obat dan sisa persediaan. Nilai persediaan dihitung tiap minggu merupakan persediaan dikurangi jumlah pemakaian obat sebagai sisa stok selanjtnya dikalikan dengan harga (Indrajit dkk, 2014).

Tingkat pelayanan. Customer Service Level diukur menggunakan persentase. Untuk menghitung tingkat efektivitas persediaan barang, digunakan rasio layanan atau tingkatan pelayananan. Rasio pelayananan / tingkatan pelayananan mewakili rasio atau perbandingan dua metrik tertentu, dan tingkat layanan menunjukkan tingkat layanan tertentu (Persamaan 3). Tingkat layanan mengacu pada rasio antara kuantitas / nilai permintaan yang dapat dipenuhi oleh pasokan dan nilai total dari semua permintaan pengguna (Indrajit dkk, 2014).

$$
\text { Tingkat Pelayanan }=\frac{\text { Jumlah permintaan terpenuhi }}{\text { Jumlah seluruh permintaan }}
$$

Persamaan 3. Rumus perhitungan tingkat pelayanan untuk menghitung tingkat efektivitas persediaan barang.

\section{Hasil dan Pembahasan}

\subsection{Analisis $A B C$}

Metode analisa $A B C$ digunakan untuk mengetahui obat BPJS yang menyerap anggaran yang paling banyak. Dengan penerapan metode $A B C$ dapat meminimalkan kekosongan yang akan berdampak pada kepuasan pasien terhadap pelayanan rumah sakit. Hasil analisis dengan menggunakan metode $A B C$ berdasarkan jumlah pemakaian obat BPJS (Tabel 1) menunjukkan cara mengelola obat akan lebih mudah karena peramalan yang lebih baik, pengendalian persediaan dan kendala pemasok.

Obat kelompok $A$ merupakan obat yang menghabiskan $75 \%$ dari total biaya serta jumlah obat $20 \%$ total jumlah obat. Obat kelompok $B$ merupakan obat yang menghabiskan $20 \%$ dari total biaya serta jumlah obat $30 \%$ dari total jumlah obat, sedangkan obat $C$ merupakan obat menghabiskan $5 \%$ dari total biaya sedangkan jumlah obatnya $50 \%$ dari total jumlah obat.

Golongan $A$ merupakan obat kronis seperti hipertensi, diabetes dan stroke merupakan obat yang cepat menyebar (Tabel 1). Oleh karena itu, penanganan obat kronis memerlukan pengolahan tambahan untuk memastikan tidak ada persediaan yang kosong. Obat dengan harga tinggi dan sedang akan dimasukkan ke dalam obat golongan $B$, sedangkan obat dengan harga murah dan jarang digunakan akan dimasukkan ke dalam golongan $C$. 
Tabel 1. Hasil pengelompokkan obat BPJS dengan metode $A B C$ berdasarkan nilai pemakaian di Instalasi Farmasi Rumah Sakit Bhayangkara Tk. III Nganjuk bulan Februari - Juli 2019.

\begin{tabular}{ccccc}
\hline Kelompok & Jumlah Item & \% Item & Nilai Pemakaian $($ Rp) & \% Pemakaian \\
\hline A & 40 & 13 & 409.412 .034 & 75 \\
B & 81 & 27 & 110.039 .489 & 20 \\
C & 181 & 60 & 27.387 .687 & 5 \\
\hline Total & $\mathbf{3 0 2}$ & $\mathbf{1 0 0}$ & $\mathbf{5 4 6 . 8 3 9 . 6 8 7}$ & $\mathbf{1 0 0}$ \\
\hline
\end{tabular}

Jika dibandingkan dengan penelitian oleh Kristijono (2018) yang dilakukan pada era BPJS, cara pengelompokkan obat dengan menggunakan metode $A B C$ berdasarkan metode konsumsi kelompok $A$ dengan nilai pemakaian tertinggi sebesar $80 \%$, kelompok $B$ nilai pemakaian $14 \%$, kelompok C nilai pemakaian 6\%. Sedangkan hasil penelitian yang obat BPJS oleh Susanto (2017) pada rumah sakit tipe B di kota Jakarta dengan menggunakan analisis $A B C$, dengan jumlah item obat 2052, kelompok $A$ nilai pemakaian tertinggi sebesar 70,14\%, kelompok $B$ serta kelompok $C$ nilai pemakaian 9,99\% juga menentukan nilai pemakaian obat berdasarkan dampaknya terhadap kesehatan pasien dengan pertimbangan efesiensi penggunaan dana yang ada. Tetapi ada perbedaan dengan penelitian oleh Khuriyati (2015) dimana kelompok $A$ dengan nilai pemakaian $60 \%$, kelompok $B$ dengan nilai pemakaian $30 \%$ dan kelompok $C$ dengan nilai pemakaian hingga 10\%. Dibandingkan penelitian Rofiq (2019) kelompok obat $A$ nilai pemakaian tertinggi 74,98\%, kelompok obat $B$ nilai pemakaian $15,02 \%$ dan pemakaian obat $C$ nilai pemakaian $10 \%$. Penelitian Tina (2016) pada obat antibiotik obat $A$ nilai pemakaian 9\%, obat $B$ nilai pemakaian $13 \%$ dan obat $C$ nilai pemakian sebesar $78 \%$. Perbedaan ini tergantung dari referensi yang diambil peneliti tetapi ketika persentasenya berbeda sedikit hasilnya. Tanpa analisis $A B C$ dimungkinkan akan dilakukan upaya besar untuk mencoba mengatur semua obat BPJS dengan prioritas yang sama sehingga menjadi tidak efektif secara keseluruhan.

\subsection{Analisa Kombinasi $A B C V E N$}

Metode gabungan $A B C$ dan $V E N$ digunakan untuk memprioritaskan metode pengadaan obat dari segi efisiensi atau anggaran berdasarkan kebutuhan pendanaan (Satibi, 2015). Tabel 2 menunjukkan hasil dari interview yang telah dilakukan peneliti dengan kepala instalasi bagian farmasi dan ditampilkan hasil klasifikasin obat-obatan dnegan metode $V E N$, sedangkan metode pengadaan obat di Rumah Sakit Bhayangkara Tk. III Nganjuk menggunakan metode konsumsi sesuai dengan kebutuhan obat di rumah sakit tersebut untuk menghindari kekosongan obat.

Tabel 2. Hasil pengelompokkan obat BPJS dengan metode VEN di Instalasi Farmasi Rumah Sakit Bhayangkara Tk. III Nganjuk bulan Februari - Juli 2019. 


\begin{tabular}{cc}
\hline Kelompok & Jumlah Item \\
\hline V & 43 \\
E & 249 \\
N & 10 \\
\hline Total & $\mathbf{3 0 2}$ \\
\hline
\end{tabular}

Kombinasi $\mathrm{ABC}$ dan VEN perlu dianalisis untuk mengklasifikasikan obat. Kombinasi kedua metode tersebut menunjukkan pentingnya memprioritaskan setiap obat. Berdasarkan kepentingan klinisnya analisa VEN dilakukan oleh apoteker RS Bhayangkara Tk. III Nganjuk. Jika dibandingkan dengan penelitian yang dilakukan oleh Budiman (2017) pada saat era BPJS pengelompokan $V E N$ obat diperoleh hasil kelompok $V$ dengan jumlah obat 174 item, kelompok $E$ dengan jumlah 1.093 dan kelompok $N$ dengan jumlah 274 item. Dimungkinkan dalam penggelompokan prioritas di tiap rumah sakit berbeda karena pengelompokan obat dengan metode $V E N$ dilakukan oleh apoteker rumah sakit setempat dan hal ini ditentukan oleh faktor makro (seperti peraturan pemerintah atau data epidemiologi daerah) dan faktor mikro (seperti jenis layanan medis yang disediakan oleh rumah sakit).

Dari hasil analisa kombinasi $A B C$ dan $V E N$ di IFRS Bhayangkara Tk.III Nganjuk didapat 29 item obat BPJS kategori $A E$ dari total 302 item obat BPJS yang diperoleh dari bulan Februari sampai Juli 2019. Obat BPJS kelompok $A E$ memberikan gambaran kepada pihak IFRS Bhayangkara Tk.III Nganjuk dalam seleksi dan perencanaan pengadaan obat mana saja yang perlu pengawasan ketat karena menyerap anggaran yang tinggi, pemakaian yang tinggi dan masuk dalam kategori fast moving agar obat tetap tersedia IFRS Bhayangkara Tk.III Nganjuk sehingga pelayan resep kepada pasien dapat berjalan optimal dan efisien.

\subsection{Analisis EOQ}

Tujuan dari Metode EOQ adalah untuk memperhitungkan total pesanan dengan tingkatan paling ekonomis yang harus dipesan oleh pihak RS Bhayangkara Tk.III Nganjuk yang tetap memperhatikan pembiayaan dari total pemesanan dan pembiayaan penyimpanan. Metode $E O Q$ bila diterapkan dengan benar akan dapat menurunkan biaya penyimpanan, resiko kerusakan obat dan menurunkan angka kadaluarsa obat. Tabel 3 menunjukkan hasil perhitungan $E O Q$ masing-masing obat di RS Bhayangkara Tk. III Nganjuk dapat mengurangi biaya penyimpanan dan risiko kerusakan / pembatalan obat dengan menggunakan metode $E O Q$, meskipun biaya pemesanan dapat ditingkatkan namun dapat menghemat banyak biaya. Penentuan persediaan obat sangat penting bagi IFRS karena akan mempengaruhi biaya investasi, biaya penyimpanan dan keuntungan rumah sakit. Kesalahan dalam menentukan ukuran bahan akan mempengaruhi anggaran, menyerap dana tahunan rumah sakit dalam jumlah besar dan meningkatkan biaya penyimpanan. 
Tabel 3. Perhitungan $E O Q$ di Instalasi Farmasi Rumah Sakit Bhayangkara Tk. III Nganjuk bulan Februari - Juli 2019.

\begin{tabular}{llcrrrr}
\hline No. Nama Obat & $\begin{array}{c}\text { Jumlah } \\
\text { Pemakaian } \\
\text { (Unit) }\end{array}$ & $\begin{array}{c}\text { Biaya } \\
\text { Pemesanan } \\
\text { (Rp) }\end{array}$ & $\begin{array}{c}\text { Harga Beli } \\
\text { (Rp) }\end{array}$ & $\begin{array}{c}\text { Biaya } \\
\text { Penyimpanan } \\
\text { 18,50\% dari } \\
\text { Harga beli } \\
\text { (Rp) }\end{array}$ & $\begin{array}{c}\text { EOQ } \\
\text { (Unit) }\end{array}$ \\
\hline 1 & Amlodipin 10mg & 7.880 & 13.704 & 500 & 93 & 1.528 \\
2 & Amlodipin 5mg & 6.900 & 13.704 & 4.400 & 81 & 1.524 \\
3 & Asam Valporat Syr & 1.400 & 13.704 & 15.788 & 2.921 & 115 \\
4 & Cefadroxil 250mg Syr & 982 & 13.704 & 3.992 & 726 & 193 \\
5 & Cefoperazon Sulbactam & 300 & 13.704 & 60.500 & 11.193 & 27 \\
\hline
\end{tabular}

Metode EOQ bertujuan untuk meminimalisir total biaya persediaan obat dengan menyeimbangkan biaya pemesanan dan biaya penyimpanan. Pengadaan obat yang lebih rendah dibanding dengan $E O Q$ dapat menyebabkan pemberiaan obat dalam jumlah besar untuk setiap kali pemesanan. Adanya persediaan yang terlalu besar akan menambah biaya penyimpanan dan biaya pemesanan yang akan mengurangi keuntungan, sebaliknya persediaan yang kecil akan mengakibatkan pelayanan terganggu sehingga menimbulkan kerugian juga.

\subsection{Analisis ROP}

Masing-masing obat BPJS yang dihitung kategori $A E$ mempunyai nilai $R O P$ yang berbeda dan memerlukan pengawasan yang ketat. Dalam hitungan ROP, prediksi dari lead time untuk barang sampai di RS Bhayangkara Tk.III Nganjuk dari pihak distributor diperkirakan 2 hari berdasarkan wawancara dengan kepala IFRS Bhayangkara Tk.III Nganjuk. Untuk menghindari terjadinya kekosongan obat dalam metode $R O P$, EOQ menjawab pertanyaan kapan seharusnya pemesanan dilakukan dan ini adalah fungsi dari EOQ, lead time Ini digunakan untuk memperkirakan pasokan yang akan tiba sebelum habis. ROP dihitung dari 2 kali safety stock. Safety stock yakni menghindari fluktuasi permintaan.

Tabel 4. Perhitungan ROP di Instalasi Farmasi Rumah Sakit Bhayangkara Tk. III Nganjuk bulan Februari - Juli 2019.

\begin{tabular}{llcccc}
\hline No & \multicolumn{1}{c}{ Nama Obat } & $\begin{array}{c}\text { LT / } \\
\text { Lead } \\
\text { Time } \\
\text { (Hari) }\end{array}$ & $\begin{array}{c}\text { SS / } \\
\text { Safety } \\
\text { Stock } \\
\text { (Unit) }\end{array}$ & $\begin{array}{c}\text { ROP/ } \\
\text { Reorder } \\
\text { Point } \\
\text { (Unit) }\end{array}$ & $\begin{array}{c}\text { Maximum Level } \\
\text { Inventory } \\
\text { (Unit) }\end{array}$ \\
\hline 1 & Amlodipin 10mg & 2 & 43 & 86 & 1.571 \\
2 & Amlodipin 5mg & 2 & 38 & 76 & 1.562 \\
3 & Asam Valporat Syr & 2 & 8 & 15 & 122 \\
4 & Cefadroxil 250mg Syr & 2 & 5 & 11 & 198 \\
5 & Cefoperazon Sulbactam & 2 & 2 & 3 & 29 \\
\hline
\end{tabular}

Manajemen perencanaan dan pengadaan berdasarkan metode $A B C, E O Q$, dan $R O P$ ialah salah satu usaha yang diharapkan dapat mengatur kendali pembiayaan untuk lebih efisien dengan besamya nilai pemakaian yang ditanam di dalam nilai persediaan. Besarnya nilai pemakaian obat-obat BPJS akan berpengarug pada besarnya belanja IFRS Bhayangkara 
Tk.III Nganjuk secara keseluruhan, dan belanja IFRS Bhayangkara Tk.III Nganjuk dapat berpengaruh terhadap jumlah pembelanjaan oprasional rumah sakit, namun jika terjadi kemungkinan tingkat efisien dalam mengelola persediaan di IFRS Bhayangkara Tk.III Nganjuk maka sendirinya akan terjadi efisiensi operasional di RS Bhayangkara Tk.III Nganjuk.

Menurut Devina (2016) masalah yang dialami dalam pengendalian persediaan adalah waktu pengiriman dalam waktu yang bervariasi dan kekosongan obat. Pengendalian obat BPJS hampir sama dengan obatreguler, namun karena kejadian kekosongan distributor lebih tinggi dari pada obat konvensional maka lead time dan penghitungan ROP berbeda, sehingga perhitungan pembelian obat BPJS harus dilakukan. Kekosongan obat BPJS di ganti dengan obat lain dengan obat lain yang memiliki komposisi sama dan harga yang mirip dengan yang ada di e-catalog. Kekosongan obat rawat jalan akibat keterlambatan persalinan dapat diatasi dengan menunda penggunaan obat pasien. Kepatuhan dokter yang menulis resep BPJS sesuai spesifikasi BPJS tidak 100\%. Kebijakan rumah sakit untuk mengatasi perbedaan harga obat adalah dengan menyelamatkan bagian lain yaitu mengefektifkan pengobatan, BHP Billiton, dan menggunakan alat kesehatan yang murah. Dewan direksi menentukan kebijakan rumah sakit dalam memutuskan pemberian obat BPJS di luar TNI dengan menentukan apakah pasien benar-benar membutuhkan obat tersebut dan apakah ada obat alternatif lain yang masuk BPJS serta penetapan harga obat.

\subsection{Nilai Persediaan}

Tahap sebelum intervensi pengendalian pengadaan obat BPJS kategori $A E$ dengan memakai metode $E O Q$ yang disertai $R O P$ memudahkan dalam perencanaan pengadaan dan juga memudahkan kapan akan dilaksanakan pemesanan kembali. Hal ini dilakukan dengan tetap memperhitungkan sisa stok obat yang ada dan penurunan nilai persediaan pada saat sebelum intervensi bulan Februari sampai April dan setelah intervensi bulan Mei sampai Juli 2019. Menurut Maimum (2008), belum efisiennya anggaran biaya obat di suatu instalasi farmasi rumah sakit terlihat dari tingginya nilai persediaan. Selama proses intervensi dilaksanakan, pemesanan obat dilakukan berdasarkan nilai $E O Q$ yang didapatkan dari hasil perhitungan dengan tetap mempertimbangkan nilai $R O P$ yang diperoleh, sehingga diharapkan tidak akan terjadi stock out dalam proses pelayanan yang dilakukan.

Tabel 5. Nilai persediaan obat sebelum dan setelah intervensi di Instalasi Farmasi Rumah Sakit Bhayangkara Tk. III Nganjuk bulan Februari - Juli 2019. Tanda asterisk (*) menunjukkan nilai signifikansi dengan taraf kepercayaan $95 \%$ menggunakan uji $t$ test. Sumber : IFRS Bhayangkara Tk. III Nganjuk.

\begin{tabular}{|c|c|c|c|c|}
\hline Tahap & Bulan & $\begin{array}{l}\text { Nilai Persediaan } \\
\text { (Rp) }\end{array}$ & $\begin{array}{c}\text { Rerata Nilai Persediaan } \\
\text { (Rp) }\end{array}$ & $\begin{array}{l}\text { Tingkat } \\
\text { Signifikan }\end{array}$ \\
\hline
\end{tabular}




\begin{tabular}{lllrl}
\hline Sebelum & Februari & 409.412 .034 & 403.114 .341 & $0,043^{*}$ \\
intervensi & Maret & 421.834 .578 & \pm 18.402 .943 & \\
& April & 378.096 .412 & & \\
Setelah & Mei & 340.591 .682 & 331.170 .915 & \\
Intervensi & Juni & 321.896 .271 & \pm 7.633 .068 & \\
& Juli & 331.024 .792 & & \\
\hline
\end{tabular}

Tabel 4 menunjukkan pada tahap sebelum dilakukannya intervensi Februari sampai April rata-rata nilai persediaan sebesar Rp. 403.114.341. Pada tahap setelah dilakukannya intervensi bulan Mei sampai Juli, hasil menunjukkan penurunan yaitu sebesar Rp. 71.943.426 rata-rata nilai persediaan setelah intervensi sebesar Rp. 331.170.915. Pada tahap setelah intervensi terlihat penurunan nilai persediaan, tahap sebelum intervensi ke tahap saat intervensi yang menunjukkan penurunan nilai persediaan. Wajar saja jika terjadi penurunan nilai rata-rata persediaan pada masa intervensi ini yaitu pada bulan Mei sampai Juli, karena intervensi yang dilakukan mampu memberikan efektifitas dan efisiensi.

Penelitian Hartih (2014) yang dilakukan pada obat reguler bahwa pada tahap intervensi nilai persediaan yang masih mengalami fluktuasi namun cenderung menurun pada bulan berikutnya. Nilai persediaan menurun sesudah diterapkannya intervensi sebesar Rp. 436.971.472,-. Penurunan nilai persediaan berarti memberikan keuntungan bagi rumah sakit karena dapat menghemat biaya penyimpanan dan biaya pemesanan.

Analisis data menggunakan analisis paired T-test, untuk data perbandingan yakni sebelum dan sesudah intervensi. Data tabel 4 mengidentifikasikan ketidaksamaan sebelum dan setelah penggunaan metode $E O Q$ dan $R O P$ pada nilai persediaan menunjukkan hasil yang signifikan, dilihat dari hasil $\mathrm{P}<0,05$ hal ini menegaskan bahwa pengadaan barang dengan menggunakan metode $E O Q$ dan $R O P$ berbeda signifikan dengan peningkatan nilai persediaan sebelum dilakukan intervensi.

\subsection{Tingkat Pelayanan/Customer Service Level}

Efektivitas pengelolaan obat guna menggambarkan seberapa jauh persediaan obat berguna atau mendukung operasional instalasi farmasi di suatu rumah sakit dapat diukur menggunakan indikator tingkat pelayanan resep (Customer Service Level). Pengukuran tingkat pelayanan (Costumer Service Level) biasanya digunakan rasio layanan atau tingkat pelayanan, dengan membandingkan antara jumlah semua resep $(R /)$ yang masuk dengan jumlah resep $(R /)$ yang tidak terlayani pada bulan tersebut yang masuk pada IFRS Bhayangkara Tk.III Nganjuk.

Penggunaan metode $E O Q$ dan $R O P$ yang telah dilakukan merupakan upaya pengontrolan dan pemantauan persediaan obat agar obat yang diberikan tepat waktu dan 
kekosongan persediaan obat dapat dihindari. Karena dengan tersediannya obat akan menunjang pemenuhan obat kepada pasien.

Tabel 6. Nilai tingkat pelayanan (customer service level) sebelum dan setelah intervensi di Instalasi Farmasi Rumah Sakit Bhayangkara Tk. III Nganjuk bulan Februari - Juli 2019. Tanda asterisk (*) menunjukkan nilai signifikansi dengan taraf kepercayaan $95 \%$ menggunakan uji t-test. Sumber : IFRS Bhayangkara Tk. III Nganjuk.

\begin{tabular}{llrrrrr}
\hline \multicolumn{1}{c}{ Tahap } & Bulan & $\begin{array}{c}\text { Jumlah } \\
\text { Permintaan } \\
\text { terlayani }\end{array}$ & $\begin{array}{c}\text { Jumlah } \\
\text { seluruh } \\
\text { permintaan }\end{array}$ & $\begin{array}{c}\text { Tingkat } \\
\text { Pelayanan } \\
(\boldsymbol{\%})\end{array}$ & $\begin{array}{c}\text { Rerata } \\
\text { Pelayanan } \\
(\mathbf{\%})\end{array}$ & $\begin{array}{c}\text { Tingkat } \\
\text { Signifikan }\end{array}$ \\
\hline Sebelum & Februari & 3.875 & 4.252 & 91,13 & 91,76 & $0,025^{*}$ \\
Intervensi & Maret & 3.979 & 4.334 & 91,80 & $\pm 0,50$ & \\
& April & 3.970 & 4.298 & 92,36 & & \\
Setelah & Mei & 4.025 & 4.233 & 95,08 & 94,39 & \\
Intervensi & Juni & 4.109 & 4.394 & 93,51 & $\pm 0,65$ & \\
& Juli & 4.054 & 4.285 & 94,60 & & \\
\hline
\end{tabular}

Tabel 5 menunjukkan bahwa tingkat pelayanan IFRS Bhayangkara Tk.III Nganjuk cenderung efektif, terlihat dari rasio resep setelah intervensi meningkat dari 91,76\% menjadi $94,39 \%$, mencapai hampir $100 \%$. Semakin tinggi service level maka supply dapat memenuhi dan memenuhi permintaan alat farmasi yang artinya sudah efektif. Tingkat pelayanan tertinggi adalah $100 \%$ yang artinya kepuasan pasien yang membutuhkan pengobatan dapat terpuaskan atau terpuaskan. Rasio layanan minimum adalah $0 \%$, di mana tidak ada permintaan obat yang dapat dipenuhi.

Indikator kepuasan pelanggan menurut Menteri Kesehatan Republik Indonesia Nomor: 129/Menkes/SK/II/2008 (Depkes RI, 2008) Tentang Standar Pelayanan Minimal Rumah Sakit standar yang di tetapkan adalah $\geq 80 \%$ sedangkan penelitian yang dilakukan sebelum intervensi tingkat pelayanan di RS Bhaynagkara Tk.III Nganjuk 92,13\% angka tesebut sudah diatas nilai angka standar.

Data statistik penelitian ini menunjukkan hasil berbeda signifikan antara data sebelum dan setelah intervensi dilakukan. Dari pengujian yang menampilkan $\mathrm{P}<0,05$ memiliki makna bahwasannya ada perbedaan signifikan antara tahap sebelum dan setelah intervensi. Ini menunjukkan bahwa penerapan $E O Q$ dan $R O P$ memberikan pengaruh nyata terhadap tingkat layanan. Penerapan analisis $E O Q$ dan $R O P$ dalam pemesanan/pengadaan obat BPJS kategori $A E$ dapat memberikan pengaruh yang positif terhadap nilai tingkat layanan yang terlihat dari sebelum dan setelah intervensi walaupun pengaruhnya kecil. Hal ini disebabkan pelayanan resep obat pasien BPJS harus tetap terpenuhi walaupun stok obat BPJS di instalasi farmasi habis atau stock out. Dampak yang diberikan dari penerapan analisis EOQ dan ROP dalam pemesanan/pengadaan obat BPJS kategori $A E$ memberikan pengaruh yang positif terhadap nilai persediaan dan tingkat pelayanan yang terlihat dari sebelum dan setelah intervensi. 


\section{Kesimpulan}

Metode gabungan antara $A B C$ dan $V E N$ dapat mengidentifikasi obat-obatan yang memerlukan pengendalian persediaan yang lebih ketat dan memprioritaskan 29 item obat BPJS kategori $A E$ di RS Bhayangkara Tk.III Nganjuk. Penerapan intervensi nilai persediaan dengan metode $E O Q$ dan $R O P$ sebelum intervensi Rp. 403.114.341 dan setelah intervensi Rp. 331.170.915 dapat meningkatkan efesiensi pengelolaan obat BPJS dan menurunkan nilai persediaan sebesar Rp 71.943.426. Hasil analisis statistik Paired t-Test menunjukkan hasil signifikan (0,043). Penerapan intervensi tingkat pelayanan (customer servis level) sebelum intervensi $91,76 \%$ dan setelah intervensi $94,39 \%$ hasil analisis statistik Paired t-Test menunjukkan hasil signifikan $(0,025)$ meningkatkan efektifitas tingkat pelayanan (customer servis level) di RS Bhayangkara Tk.III Nganjuk.

\section{Ucapan Terima Kasih}

Penulis ucapkan terimakasih kepada pihak RS Bhayangkara Tk. III Nganjuk, Universitas Setia Budi dan Staf Instalasi Farmasi Rumah sakit Bhayangkara Tk. III Nganjuk dengan bantuannya, peneliti dapat melakukan penelitian dari pengumpulan data sampai kesimpulan dari hasil penelitian.

\section{Deklarasi Konflik Kepentingan}

Pihak peneliti menyatakan dengan penelitian ini tidak ada sangkutpaut terhadap konflik yang berhubungan dengan penelitian.

\section{Daftar Pustaka}

Budiman, P, O. (2017). Analisis Perencanaan Obat Berdasarkan ABC Indeks Kritis Di Instalasi Farmasi RS PKU Muhammadiyah Yogyakarta. Tesis. Program Studi Manajemen Rumah Sakit, Universitas Muhamadiyah, Yogyakarta.

Depkes RI. (2008). Menteri Kesehatan Republik Indonesia Nomor: 129/Menkes/SK/II/2008

Tentang Standar Pelayanan Minimal Rumah Sakit. Departemen Kesehatan Republik Indonesia, Jakarta.

Devina, E. M., Chriswardani, S. (2016). Analisis Pengelolaan Obat Pasien BPJS Di Instalasi Farmasi Rumah Sakit Panti Wilasa Citarum Semarang. Jurnal Manajemen Kesehatan, 4 (3).

Hartih, A.N. (2014). Penerapan Metode Economic Oeder Quantity dan Reorder Point Dalam Meningkatkan Efisiensi Persediaan Obat Reguler di Instalasi Farmasi RSUD Lansirang Kabupaten Pinrang. Tesis, Program Studi Ilmu Farmasi, Universitas Setia Budi, Surakarta.

Handoko, T.H. (2003). Pengantar Manajemen. Ed.II, Cetakan ke enam belas, BPFE, Yogyakarta.

Heizer, J. dan Render, B. (2011). Production and Operation Management. Buku 1 edisi ke Sembilan, Salemba empat, Jakarta. 
Indrajit, R., Djokopranito, E.R. (2014). Manajemen Persediaan. PT. Gramadia Widiasarana, Indonesia Jakarta.

Khuriyati, I.L. (2015). Pengendalian Persediaan Obat Kemoterapi Melalui Pendekatan Analisis ABC Indeks Kritis di Ruang Pencampuran Instalasi Farmasi RSUP Dr. Mohammad Hosein Palembang. Tesis, Program Studi Pasca Sarjana Kajian Administrasi dan Kebijakan Kesehatan Fakultas Kesehatan Masyarakat, Universitas Indonesia, Jakarta.

Kristijono, A. (2018). Analisis Manajemen Persediaan Obat Kategori AV Dan AE Dengan Analisis ABC (Pareto) Serta VEN Pada Instalasi Farmasi RSUD Gambiran Kota Kediri. Tesis, Program Studi Ilmu Farmasi, Universitas Setia Budi, Surakarta.

Maimun, A. (2008). Perencanaan Obat Antibiotik Berdasarkan Kombinasi Metode Konsumsi Dengan Analisis ABC dan Reorder Point Terhadap Nilai Persediaan dan Turn Over Ratio di Instalasi Farmasi RS Darul Istiqomah Kaliwungu Kendal. Tesis, Program Studi Magister Ilmu Kesehatan Masyarakat, Universitas Diponegoro, Semarang.

PerMenKes. (2014). Tentang Pedoman Pelaksanaan Program Jaminan Kesehatan Nasional, PerMenKes no 28 tahun 2014, Jakarta.

PerMenKes. (2016). Standar Pelayanan Kefarmasian di Rumah Sakit. PerMenKes no 72 tahun 2016, Jakarta.

Quick, J.D., Rankin, D., Vimal. (2012). Inventory Management in Managing Drug Supplay. Third Edition. Managing Access to Medicines and Health Technologies, Arlington: Management Sciences for Health.

Rofiq. (2020). Analisis Pengendalian Persediaan Obat Dengan Metode ABC, VEN dan EOQ di Rumah Sakit Bhayangkara Kediri. Journal Pharmaceutical Science and Clinical Research, 5(2), 97-109.

Satibi. (2015). Manajemen Obat di Rumah Sakit. Fakultas Farmasi, Universitas Gajah Mada, Yogyakarta.

Susanto, A. (2017). Identifikasi Yang Mempengaruhi Total Biaya Inventori Obat-obatan Golongan A di Rumah Sakit Swasta Tipe B di Jakarta Tahun 2015. Tesis, Program Pascasarjana Manajemen Rumah Sakit, Fakultas Ilmu Kesehatan Masyarakat, Universitas Gajah Mada, Yogyakarta.

Syamsuddin dan Damayanti. (2011). Metode Penelitian Pendidikan Bahasa. Bandung: Remaja Rosdakarya.

Tina, H.Y., Yeni, F. (2016). Analisi ABC Dalam Perencanaan Obat Antibiotik di Rumah Sakit Ortopedi Surakarta. Journal Pharmaceutical Science and Clinical Research, 1 (1), 51-57.

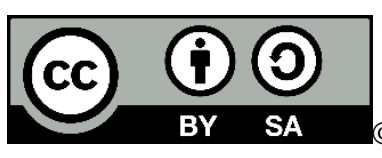

2021 by the authors. Submitted for possible open access publication under the terms and conditions of the Creative Commons Attribution-ShareAlike 4.0 International (CC BY-SA 4.0) license (https://creativecommons.org/licenses/by-sa/4.0/). 